Research Article

\title{
Study on the Heat of Hydration and Strength Development of Cast-In-Situ Foamed Concrete
}

\author{
Wenhui Zhao $\mathbb{D}^{1},{ }^{1}$ Qian Su $\mathbb{D}^{2},{ }^{2}$ Feng Han $\mathbb{D}^{1},{ }^{1}$ and Wubin Wang $\mathbb{D}^{2}$ \\ ${ }^{1}$ School of Civil Engineering, Lanzhou Jiaotong University, Lanzhou, China \\ ${ }^{2}$ School of Civil Engineering, Southwest Jiaotong University, Chengdu, China \\ Correspondence should be addressed to Wenhui Zhao; zhaowh1989@163.com
}

Received 25 September 2019; Revised 9 January 2020; Accepted 14 February 2020; Published 8 April 2020

Academic Editor: Wei Zhou

Copyright ( $\odot 2020$ Wenhui Zhao et al. This is an open access article distributed under the Creative Commons Attribution License, which permits unrestricted use, distribution, and reproduction in any medium, provided the original work is properly cited.

This study aims to investigate the relationship between the heat of hydration and the strength development of cast-in-situ foamed concrete. First, indoor model tests are conducted to determine the effects of the casting density and the fly ash content on the hydration heat of foamed concrete in semiadiabatic conditions. Second, compression tests are carried out to evaluate the development of the compressive strength with the curing time under standard curing conditions and temperature matched curing conditions. Third, the hydration heat development of the foamed concrete is tested in four projects. The results showed that the peak temperature, the maximum temperature change rate, and the maximum temperature difference increased with the increase in the casting density at different positions in the foamed concrete. For the same casting density of the foamed concrete, the peak temperature, the maximum temperature change rate, and the maximum temperature difference decreased with the increase in the fly ash content. For the foamed concrete without the admixture, the early strength was significantly higher under temperature matched curing conditions than under standard curing conditions, but the temperature matched curing conditions had a clear inhibitory effect on the strength of the foamed concrete. The strengths during the early stage and the later stage were both improved under temperature matched curing conditions after adding the fly ash, and the greater the fly ash content, the larger the effect. The maximum temperature increments were higher in the indoor model test than in the field tests for the same casting density. Reasonable cooling measures and the addition of fly ash decreased the maximum temperature increments and increased the corresponding casting times.

\section{Introduction}

Cast-in-situ foamed concrete is composed of cement, an admixture, and a proportion of stable tiny bubbles, and it is cast, molded, and cured at the construction site [1-3]. This type of concrete is a new type of geotechnical material developed in recent years and possesses the advantages of low weight, stable performance, convenient construction, and so forth. [4-7]. The applications of cast-in-situ foamed concrete have expanded considerably in civil engineering as a result of scientific and technical advances in its production. According to the statistical results of the China Concrete and Cement Products Association (CCPA), the annual market size of foamed concrete was over 40 million $\mathrm{m}^{3}$ in China during 2017, more than $80 \%$ of which was cast-in-situ foamed concrete. Due to construction growth in civil engineering, the applications of foamed concrete will also increase $[8,9]$.

Most applications of foamed concrete are in large-volume concrete construction projects. The heat generated by the hydration affects the temperature field in the structure, resulting in three problems. First, the increase and decrease of the hydration heat lead to the expansion and contraction of the foamed concrete structures, which affects the structure itself and adjacent buildings. The maximum temperature is used as an indicator of this problem. Second, a temperature difference exists between the external and internal portions of the structure and the temperature stress results in cracks in the structure's surface. This reduces the strength of the structure and affects its integrity and durability (Figure 1) $[10,11]$. Third, as studies on the impact of the hydration heat on the strength of concrete have shown [12-14] a lot of heat 


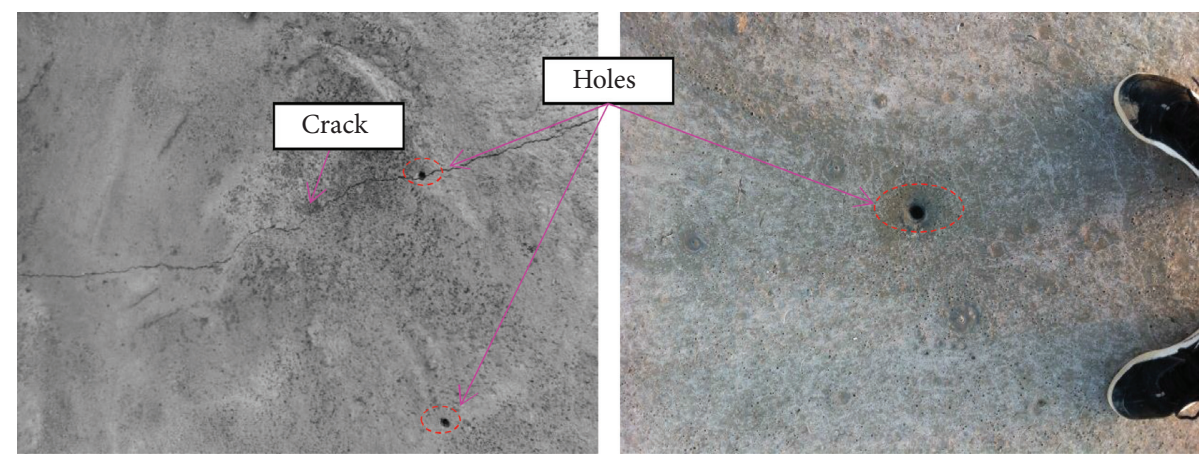

FIgURE 1: Damage to foamed concrete structures caused by hydration heat.

is produced by the hydration of foamed concrete, which may affect the strength of the material. Because the coefficient of thermal conductivity for this material is low, high temperatures are maintained for very long periods in the structure. Regarding these problems, Jones [11] stated that the heat evolution in foamed concrete is affected by a greater number of parameters than that in normal-weight concrete. Tarasov [15] studied the influence of the density and the volume of the castings and of fine aggregates on the temperature profiles in foamed concrete. However, the effect of hydration heat on the strength development of foamed concrete was not considered, and the experiments were carried out in the laboratory without considering external influencing factors.

Fly ash is a pozzolanic material and has been widely used as an admixture in concrete to address the problem of the hydration heat. Its application in concrete has been studied widely, but its application time in foamed concrete is short. Most studies on the addition of fly ash to foamed concrete have focused on the mechanical properties and durability [16-19]. If fly ash can be used satisfactorily in foamed concrete, it can be used to replace part of the cement. This lowers the construction costs and increases the performance of the foamed concrete and its application potential. The low-carbon economy is an important goal in China; therefore, the application of fly ash has a far-reaching significance $[20,21]$.

The main goal of this study is to investigate the relationship between the hydration heat and the strength development of foamed concrete. First, six groups of indoor model tests with different casting densities and different fly ash dosages were conducted to study the effects of the casting density and fly ash content on the temperature profiles of the foamed concrete. Second, compression tests under two curing conditions (standard curing, temperature matched curing) were conducted to study the effects of the curing conditions on strength development. Finally, the changes in the temperatures of the foamed concrete were analyzed in four field tests.

\section{Materials and Methods}

2.1. Materials. The foamed concrete was comprised of ordinary Portland cement, water, and bubbles. The cement was Type I Portland cement conforming to GB 175-2007, the fly ash was Class F Type I conforming to GB/T 1596-2005, and the water was tap water. The bubbles were created using a synthetic foaming agent, which was highly eco-friendly, and its air bubbles were strong [22, 23].

2.2. Mix Design Procedure. Table 1 shows the mix proportions and major parameters of the foamed concrete used in the indoor test. A prefoaming method was used to produce the foamed concrete. First, bubbles with a density of $35 \pm 5 \mathrm{~kg} / \mathrm{m}^{3}$ were prepared [24]. Second, the cement and water were weighed and mixed to produce the cement slurry. Finally, the prepared bubbles were incorporated into the cement slurry to create the foamed concrete slurry, which was then cast (Figure 2). In order to meet the requirements of the fluidity of the foamed concrete during construction, its flow value should be maintained between $160 \mathrm{~mm}$ and $180 \mathrm{~mm}$ according to the Specifications for the Design of Highway Subgrades (JTG D30-2015).

\subsection{Testing Method}

2.3.1. Indoor Model Test. The layout of the Pt-100 thermal resistance thermometers in the indoor model test, which was conducted to determine the heat of hydration of the foamed concrete, is shown in Figure 3. The size of the model was $500 \mathrm{~mm}$ long $\times 500 \mathrm{~mm}$ wide $\times 500 \mathrm{~mm}$ high. The bottom and the periphery of the model were covered with doublelayer insulating foam boards. In order to simulate the conditions at a construction site, the top surface was covered with a thin film to simulate the semiadiabatic boundary conditions after the casting of the foamed concrete. The construction time interval of each layer was about $24 \mathrm{~h}$ in construction projects, and the temperatures were acquired for $36 \mathrm{~h}$ after the casting. The tests were conducted at a room temperature of $20^{\circ} \mathrm{C}$.

2.4. Compression Test. For this test, thirty identical samples (100 mm long $\times 100 \mathrm{~mm}$ wide $\times 100 \mathrm{~mm}$ high) were cast for each mix proportion. After the casting, half of the samples were cured under standard curing conditions, and the others were cured under temperature matched curing conditions. For the standard curing condition, the samples were cured in a standard curing room after they were unmolded until the 
TABLE 1: Mix proportions and major parameters of the foamed concrete.

\begin{tabular}{cccccccccc}
\hline & $\begin{array}{c}\text { Theoretical casting } \\
\text { density }\left(\mathrm{kg} / \mathrm{m}^{3}\right)\end{array}$ & $\begin{array}{c}\text { Water/ } \\
\text { binder }\end{array}$ & $\begin{array}{c}\text { Water } \\
\left(\mathrm{kg} / \mathrm{m}^{3}\right)\end{array}$ & $\begin{array}{c}\text { Cement } \\
\left(\mathrm{kg} / \mathrm{m}^{3}\right)\end{array}$ & $\begin{array}{c}\text { Fly ash } \\
\left(\mathrm{kg} / \mathrm{m}^{3}\right)\end{array}$ & $\begin{array}{c}\text { Fly ash/ } \\
(\text { cement }+ \text { fly ash })\end{array}$ & $\begin{array}{c}\text { Air bubbles } \\
\left(\mathrm{l} / \mathrm{m}^{3}\right)\end{array}$ & $\begin{array}{c}\text { Measured casting } \\
\text { density }\left(\mathrm{kg} / \mathrm{m}^{3}\right)\end{array}$ & $\begin{array}{c}\text { Flow } \\
\text { value } \\
(\mathrm{mm})\end{array}$ \\
\hline 1 & 400 & 0.75 & 169 & 225 & 0 & 0 & 763 & 406.7 \\
2 & 700 & 0.62 & 267 & 430 & 0 & 0 & 612 & 708.4 \\
3 & 1000 & 0.54 & 346 & 640 & 0 & 0 & 448 & 1004.7 & 171.9 \\
4 & 700 & 0.62 & 267 & 386 & 43 & $10 \%$ & 609 & 707.3 & 172.3 \\
5 & 700 & 0.62 & 267 & 301 & 129 & $30 \%$ & 604 & 705.1 & 175.7 \\
6 & 700 & 0.62 & 267 & 215 & 215 & $50 \%$ & 598 & 707.9 & 179.1 \\
\hline
\end{tabular}

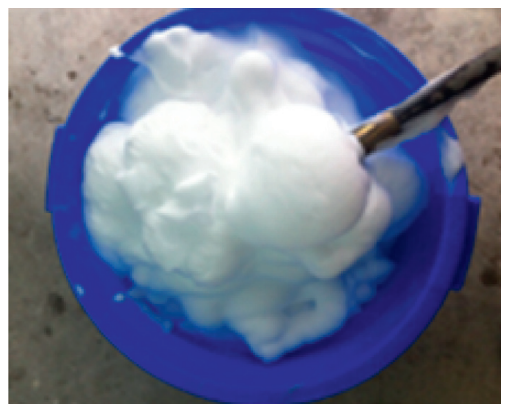

(a)

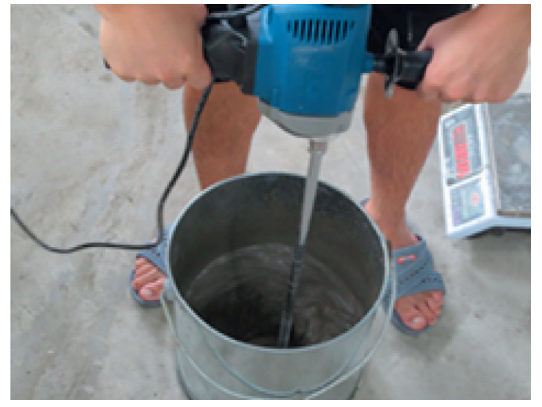

(b)

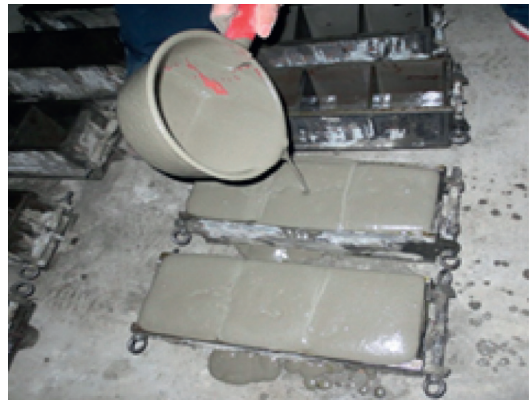

(c)

Figure 2: Preparation of the foamed concrete slurry [25].

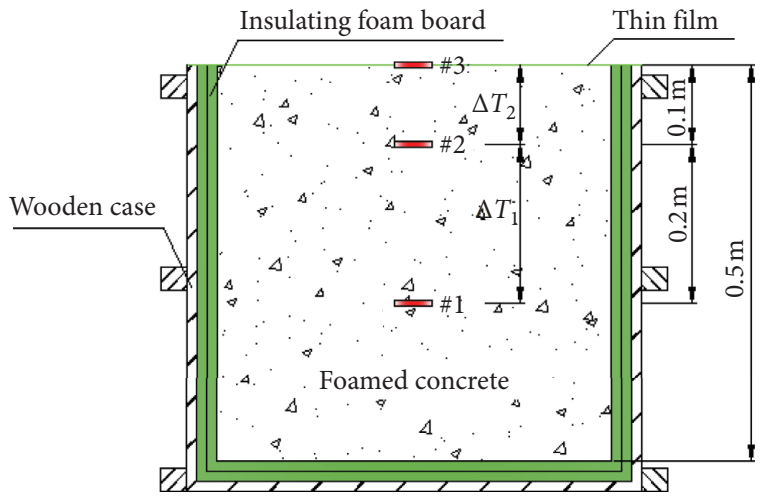

The thermometer

FIgURE 3: Profile model of the test.

test time. For the temperature matched curing conditions, the samples in the molds were placed in a constant temperature and humidity box. After the samples were unmolded, they were wrapped in bags cured in the constant temperature and humidity box (Figure 4). The temperatures for the different densities were collected in the same manner as for the indoor model test. The humidity value remained at $100 \%$.

\section{Results and Discussion}

\subsection{Effect of Casting Density on the Heat of Hydration}

3.1.1. Changes in the Temperature for Different Casting times. Figure 5 shows the relationship between the temperatures and the casting time for three casting densities in different

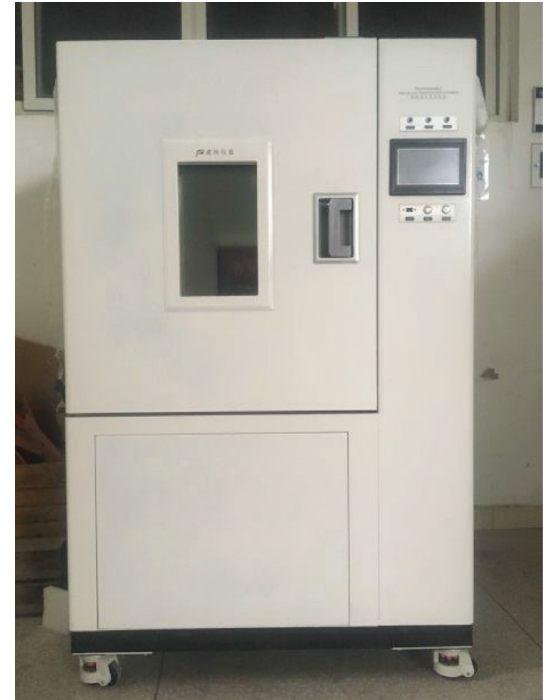

Figure 4: The constant temperature and humidity box.

positions. The results show that the temperatures first increase and then decrease with the increase in the casting time for all positions, and all three densities of the foamed concrete and peaks are observed for each curve. For the foamed concrete with the casting densities of $400 \mathrm{~kg} / \mathrm{m}^{3}$, $700 \mathrm{~kg} / \mathrm{m}^{3}$, and $1000 \mathrm{~kg} / \mathrm{m}^{3}$, the peak temperatures in position 1 are at $62.33^{\circ} \mathrm{C}, 81.03^{\circ} \mathrm{C}$, and $94.27^{\circ} \mathrm{C}$, respectively, and the corresponding times are $16 \mathrm{~h}, 15 \mathrm{~h}$, and $16 \mathrm{~h}$, respectively. For position 2 , the peak temperatures are $59.74^{\circ} \mathrm{C}$, $71.68^{\circ} \mathrm{C}$, and $82.33^{\circ} \mathrm{C}$, respectively and the corresponding times are $12 \mathrm{~h}, 14 \mathrm{~h}$, and $15 \mathrm{~h}$, respectively. For position 3 , the peak temperatures are $35.59^{\circ} \mathrm{C}, 41.30^{\circ} \mathrm{C}$, and $49.09^{\circ} \mathrm{C}$ and the 


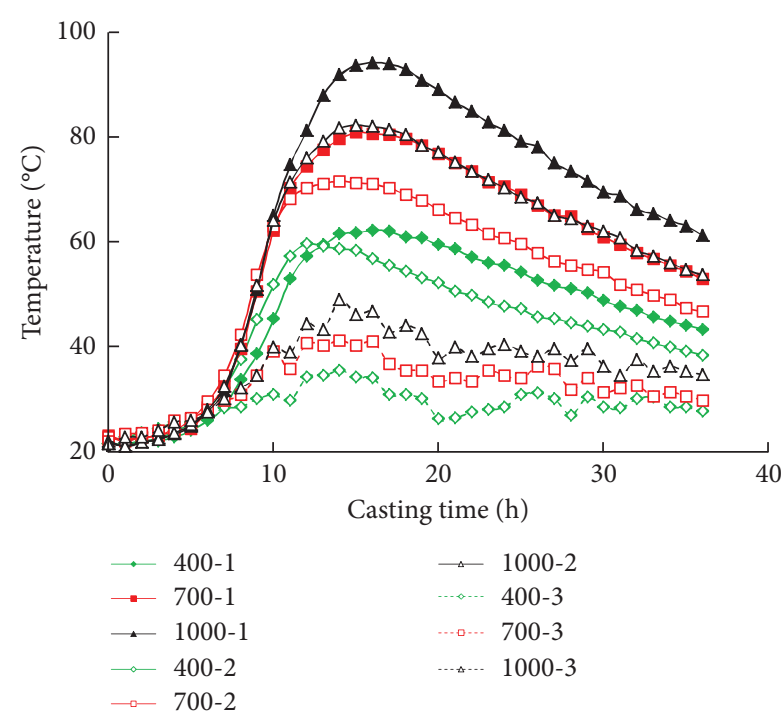

FIgURE 5: Relationship between temperatures and casting time (pure cement). Note: $400-1$ denotes the value of the test with a casting density of $400 \mathrm{~kg} / \mathrm{m} 3$ in position 1 .

corresponding time is $14 \mathrm{~h}$ for the three densities. For the same position, the peak temperature increases with the increase in the casting density of the foamed concrete. For the same casting density, the peak temperature is highest for position 1 followed by position 2 and position 3, and the corresponding times are different. This indicates that there is a heat exchange between the surface of the foamed concrete and the surrounding air.

\subsubsection{Temperature Change Rate as a Function of the Casting} Time. The relationship between the temperatures change rate and the casting time for the three casting densities in position 1 is shown in Figure 6. For the foamed concrete with a casting density of $400 \mathrm{~kg} / \mathrm{m}^{3}$, the temperature change rate reaches the maximum value of $7.5^{\circ} \mathrm{C} / \mathrm{h}$ at a casting time of $10.5 \mathrm{~h}$. For the casting densities of $700 \mathrm{~kg} / \mathrm{m}^{3}$ and $1000 \mathrm{~kg} / \mathrm{m}^{3}$, the maximum values of the temperature change rate are $11.7^{\circ} \mathrm{C} / \mathrm{h}$ and $14.3^{\circ} \mathrm{C} / \mathrm{h}$, respectively, at a casting time of $9.5 \mathrm{~h}$. The maximum value of the temperature change rate increases, and the corresponding casting time decreases with the increase in the casting density. For the three casting densities of foamed concrete, the values of the temperature change rates are below 0 at casting times longer than $15-16 \mathrm{~h}$, and the values remain stable when the casting time exceeds $20 \mathrm{~h}$. The temperature change rate is highest for the casting density of $400 \mathrm{~kg} / \mathrm{m}^{3}$, followed by the casting densities of $700 \mathrm{~kg} / \mathrm{m}^{3}$ and $1000 \mathrm{~kg} / \mathrm{m}^{3}$; therefore, the temperature attenuation increases with the increase in the casting density. In general, the temperature change rate increases before reaching the peak and the rate of temperature attenuation after the temperature peak increases with the increase in the casting density.

3.1.3. Relationship between the Temperature Difference and the Casting Time. The relationship between the temperature difference and the casting time for the three casting densities

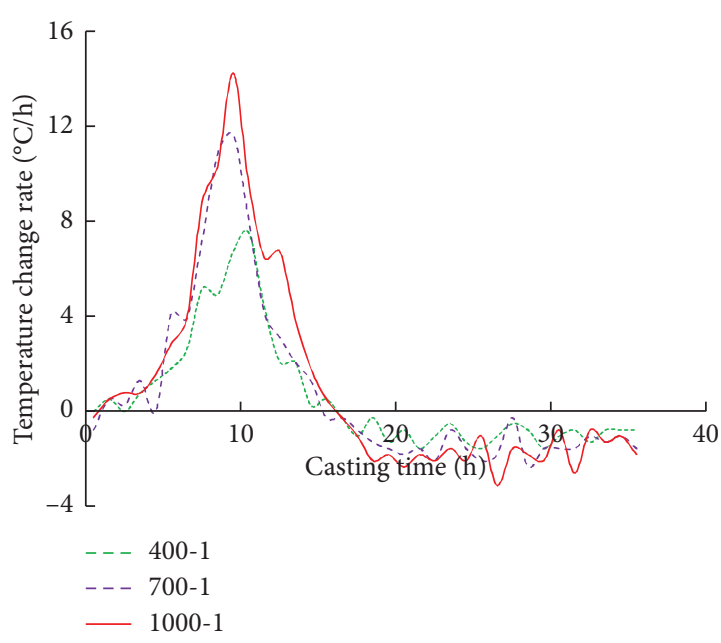

FIgURE 6: Relationship between the temperature change rate and the casting time (pure cement; \#1).

is shown in Figure 7. For the foamed concrete with the casting densities of $400 \mathrm{~kg} / \mathrm{m}^{3}, 700 \mathrm{~kg} / \mathrm{m}^{3}$, and $1000 \mathrm{~kg} / \mathrm{m}^{3}$, the maximum temperature differences $\Delta T 1$ are $8.05^{\circ} \mathrm{C}$, $10.65^{\circ} \mathrm{C}$, and $12.46^{\circ} \mathrm{C}$ and the corresponding casting times are $21 \mathrm{~h}, 20 \mathrm{~h}$, and $17 \mathrm{~h}$. The temperature differences $\Delta T 1$ first decrease and then increase to the maximum value for all the densities. After that, the values decrease slowly. For the temperature difference $\Delta T 2$ at the casting densities of $400 \mathrm{~kg} / \mathrm{m}^{3}, 700 \mathrm{~kg} / \mathrm{m}^{3}$, and $1000 \mathrm{~kg} / \mathrm{m}^{3}$, the maximum values are $27.53^{\circ} \mathrm{C}, 33.50^{\circ} \mathrm{C}$, and $39.21^{\circ} \mathrm{C}$ and the corresponding casting times are $11 \mathrm{~h}, 17 \mathrm{~h}$, and $20 \mathrm{~h}$. This indicates that for the temperature difference $\Delta T 2$, the maximum values of the temperature difference increase, and the corresponding casting times increase with the increase in the casting density.

\subsection{Effect of Fly Ash Content on the Heat of Hydration}

3.2.1. Changes in the Temperature for Different Casting Times. Figure 8 shows the relationship between the temperature and the casting time of the foamed concrete with different fly ash contents. The relationship is similar for the same casting density with different fly ash contents in the same position. For the foamed concrete with the casting density of $700 \mathrm{~kg} / \mathrm{m}^{3}$ in position 1 , at a fly ash content of $0 \%$, $10 \%, 30 \%$, and $50 \%$, the peak temperatures are $81.03^{\circ} \mathrm{C}$, $74.28^{\circ} \mathrm{C}, 63.11^{\circ} \mathrm{C}$, and $53.24^{\circ} \mathrm{C}$ and the corresponding casting times are $15 \mathrm{~h}, 17 \mathrm{~h}, 20 \mathrm{~h}$, and $24 \mathrm{~h}$, respectively. For position 2 , at a fly ash content of $0 \%, 10 \%, 30 \%$, and $50 \%$, the peak temperatures are $71.68^{\circ} \mathrm{C}, 66.75^{\circ} \mathrm{C}, 58.18^{\circ} \mathrm{C}$, and $45.97^{\circ} \mathrm{C}$ and the corresponding casting times are $14 \mathrm{~h}, 16 \mathrm{~h}, 18 \mathrm{~h}$, and $27 \mathrm{~h}$, respectively. For position 3 , at a fly ash content of $0 \%, 10 \%$, $30 \%$, and $50 \%$, the peak temperatures are $41.30^{\circ} \mathrm{C}, 38.70^{\circ} \mathrm{C}$, $35.07^{\circ} \mathrm{C}$, and $33.77^{\circ} \mathrm{C}$ and the corresponding casting times are $14 \mathrm{~h}, 14 \mathrm{~h}, 29 \mathrm{~h}$, and $28 \mathrm{~h}$, respectively. The results show that the peak temperature decreases, and the corresponding casting time increases with the increase in the fly ash content for the same casting density in the same position. 


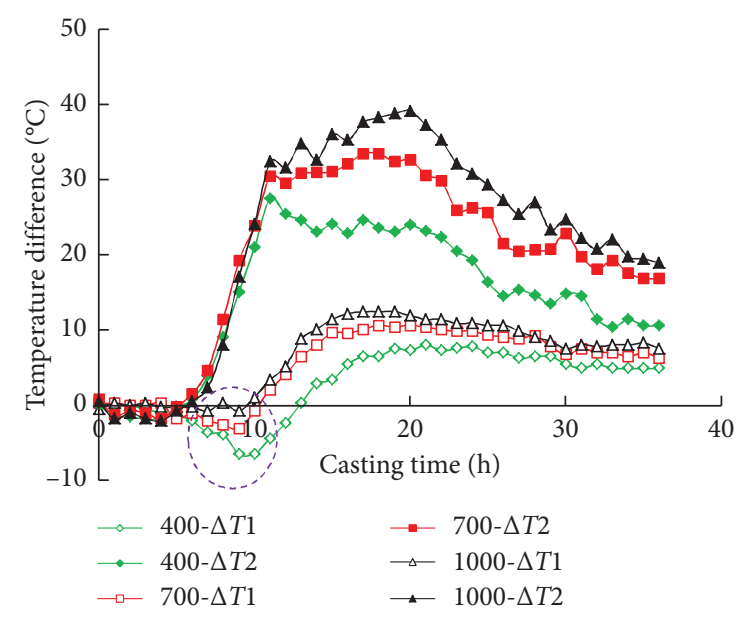

FIGURE 7: Relationship between the temperature difference and the casting time (pure cement).

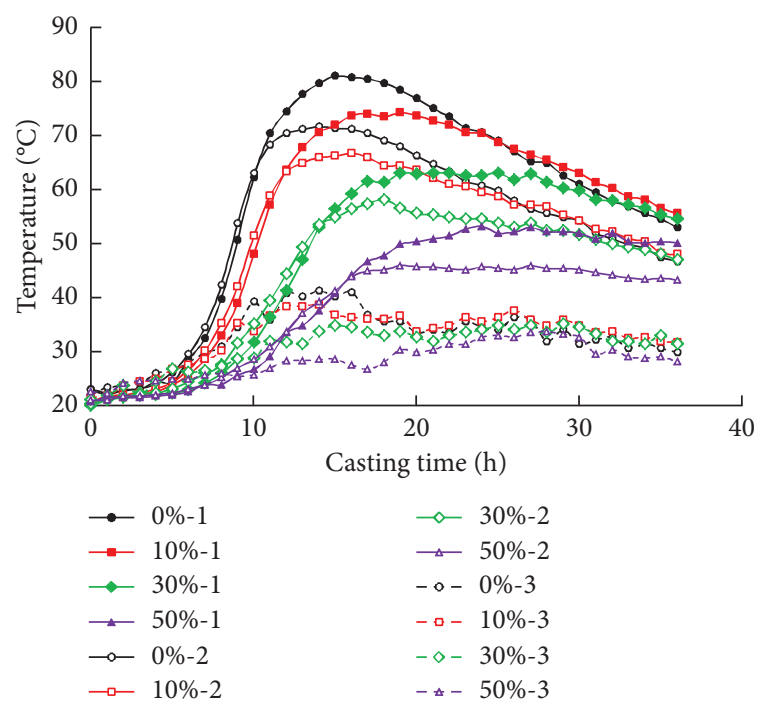

FIgURE 8: Relationship between temperature and casting time (containing fly ash). Note: $0 \%-1$ denotes the value when the fly ash content is $0 \%$ in position 1 .

\subsubsection{Temperature Change Rate as a Function of the Casting}

Time. The relationship between the temperature change rate and the casting time of the foamed concrete with different fly ash contents in position 1 is shown in Figure 9. At fly ash contents of $0 \%, 10 \%, 30 \%$, and $50 \%$, the maximum values of the temperature change rate are $11.68^{\circ} \mathrm{C} / \mathrm{h}, 9.09^{\circ} \mathrm{C} / \mathrm{h}, 5.97^{\circ} \mathrm{C} /$ $\mathrm{h}$, and $4.12^{\circ} \mathrm{C} / \mathrm{h}$ and the corresponding casting times are $9.3 \mathrm{~h}, 10.5 \mathrm{~h}, 13.5 \mathrm{~h}$, and $14.5 \mathrm{~h}$. The maximum value of the temperature change rate increases, and the corresponding time increases with the increase in the fly ash content. When the value of the temperature change rate is stable, the value increases with the increase in the fly ash content, indicating that the temperature attenuates slowly for the foamed concrete with high fly ash content.

3.2.3. Relationship between the Temperature Difference and the Casting Time. Figure 10 shows the relationship between

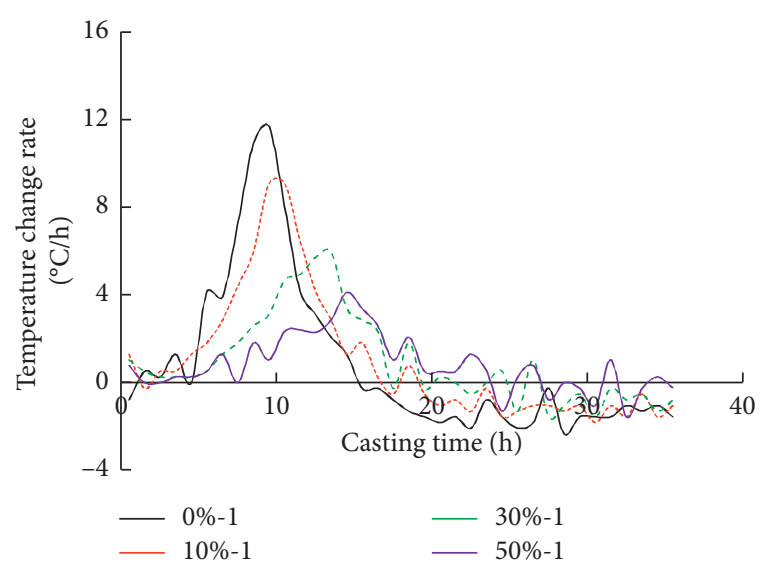

FIgURE 9: Relationship between temperature change rate and casting time (containing fly ash; \#1).

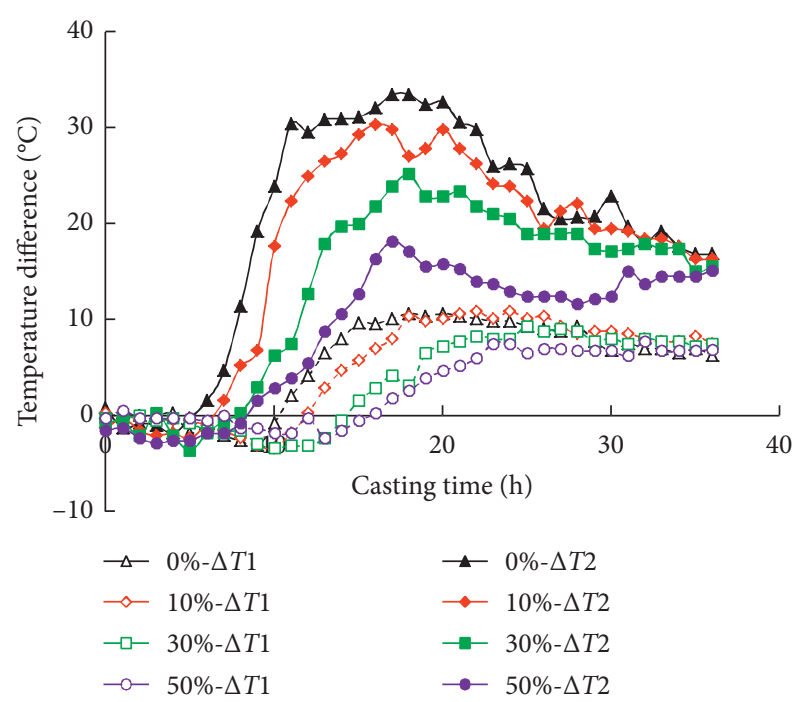

Figure 10: Relationship between the temperature difference and the casting time (containing fly ash).

the temperature difference and the casting time with different fly ash contents. At fly ash contents of $0 \%, 10 \%, 30 \%$, and $50 \%$, the maximum temperature differences $\Delta T 1$ are $10.65^{\circ} \mathrm{C}, 10.91^{\circ} \mathrm{C}, 9.35^{\circ} \mathrm{C}$, and $7.79^{\circ} \mathrm{C}$ and the corresponding casting times are $20 \mathrm{~h}, 22 \mathrm{~h}, 25 \mathrm{~h}$, and $32 \mathrm{~h}$. After reaching the maximum temperature difference, the values decrease more slowly with the increase in the fly ash content. At fly ash contents of $0 \%, 10 \%, 30 \%$, and $50 \%$, the maximum temperature differences $\Delta \mathrm{T} 2$ are $33.50^{\circ} \mathrm{C}, 30.38^{\circ} \mathrm{C}, 25.19^{\circ} \mathrm{C}$, and $18.17^{\circ} \mathrm{C}$ and the corresponding casting times are $17 \mathrm{~h}, 16 \mathrm{~h}$, $18 \mathrm{~h}$, and $17 \mathrm{~h}$. In conclusion, the maximum temperature difference increases for the same position for the same casting density with the increase in the fly ash content.

3.3. Effect of Curing Conditions on the Strength Development. Figure 11 shows the relationship between the compressive strength and the curing time for three casting densities. For the foamed concrete with the casting densities of $400 \mathrm{~kg} / \mathrm{m}^{3}$, 


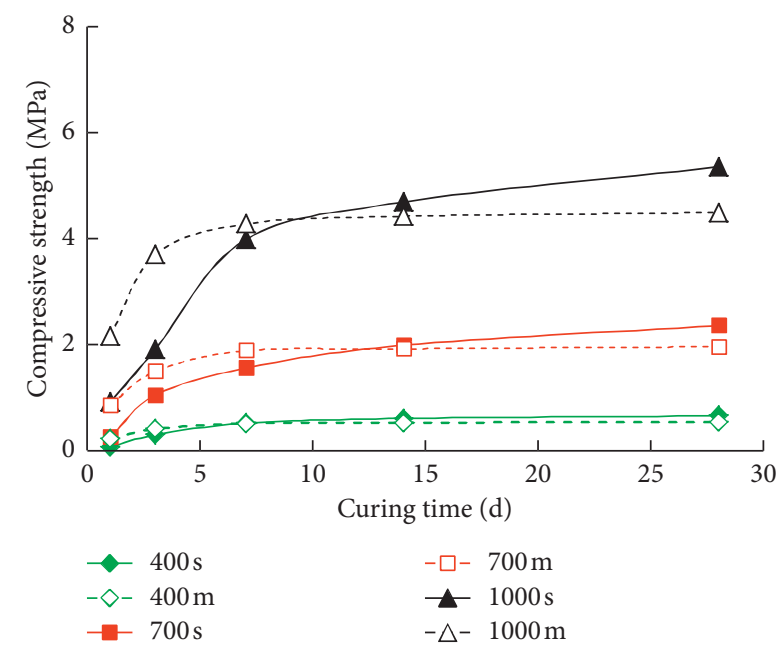

FIgURE 11: Relationship between compressive strength and curing time (pure cement). Note: $400 \mathrm{~s}$ denotes the value with the casting density of $400 \mathrm{~kg} / \mathrm{m} 3$ under standard curing conditions. $400 \mathrm{~m}$ denotes the value with the casting density of $400 \mathrm{~kg} / \mathrm{m}^{3}$ under temperature matched curing conditions.

$700 \mathrm{~kg} / \mathrm{m}^{3}$, and $1000 \mathrm{~kg} / \mathrm{m}^{3}$ under standard curing conditions, the compressive strength values are $0.065 \mathrm{MPa}$, $0.248 \mathrm{MPa}$, and $0.912 \mathrm{MPa}$, respectively, for a curing time of $1 \mathrm{~d}$ and the compressive strength values are $0.513 \mathrm{MPa}$, 1.552 $\mathrm{MPa}$, and $3.981 \mathrm{MPa}$, respectively, when the curing time is $7 \mathrm{~d}$. Under temperature matched curing conditions, the compressive strength values are $0.216 \mathrm{MPa}, 0.855 \mathrm{MPa}$, and $2.157 \mathrm{MPa}$, respectively, for a curing time of $1 \mathrm{~d}$ and $0.509 \mathrm{MPa}, 1.883 \mathrm{MPa}$, and $4.279 \mathrm{MPa}$, respectively, for a curing time of $7 \mathrm{~d}$. The comparative analysis shows that the early strength of the foamed concrete is higher under temperature matched curing conditions for the same casting density, and the improvement decreases with the increase in the curing time. For the foamed concrete with casting densities of $400 \mathrm{~kg} / \mathrm{m}^{3}, 700 \mathrm{~kg} / \mathrm{m}^{3}$, and $1000 \mathrm{~kg} / \mathrm{m}^{3}$ and $\mathrm{a}$ curing time of $28 \mathrm{~d}$, the compressive strength values are $0.654 \mathrm{MPa}, 2.359 \mathrm{MPa}$, and $5.357 \mathrm{MPa}$, respectively, under standard curing conditions and $0.535 \mathrm{MPa}, 1.959 \mathrm{MPa}$, and 4.495 MPa, respectively, under temperature matched conditions; the compressive strength values under temperature matched conditions are $81.8 \%, 83.0 \%$, and $83.9 \%$, respectively, of the values under standard curing conditions. Therefore, when the foamed concrete is mixed without the admixture, there is a promoting effect of the temperature matched conditions on the strength development in the early stage and an inhibition effect in the later stage.

The relationship between the compressive strength and the curing time with different fly ash contents is shown in Figure 12. For the foamed concrete with the casting density of $700 \mathrm{~kg} / \mathrm{m}^{3}$ and fly ash contents of $0 \%, 10 \%, 30 \%$, and $50 \%$ at curing times of $1 \mathrm{~d}, 3 \mathrm{~d}$, and $7 \mathrm{~d}$, the compressive strength values are larger for the temperature matched curing conditions than the standard curing conditions. For the foamed concrete with a casting density of $700 \mathrm{~kg} / \mathrm{m}^{3}$ and fly ash contents of $0 \%, 10 \%, 30 \%$, and $50 \%$ at a curing time of $28 \mathrm{~d}$, the compressive strength values are $2.359 \mathrm{MPa}, 2.250 \mathrm{MPa}$,

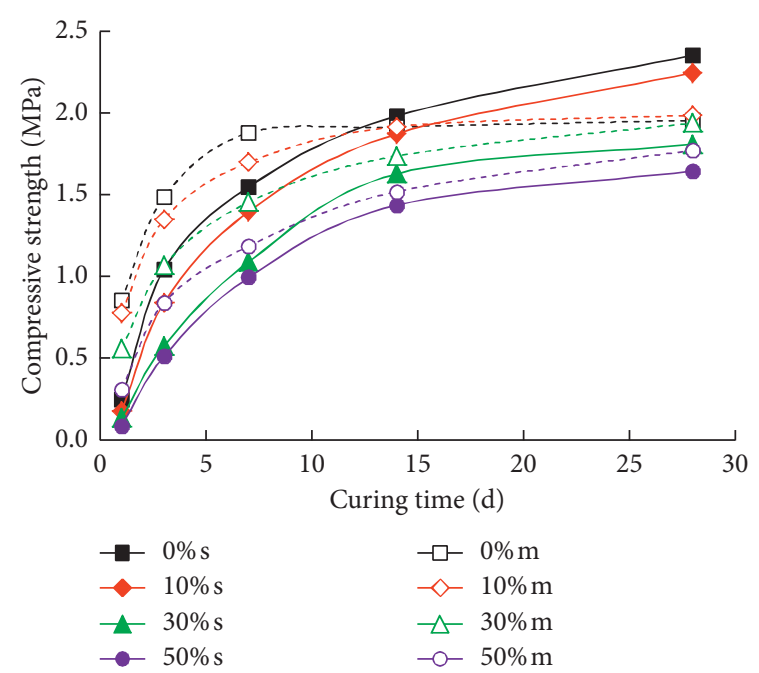

FIGURE 12: Relationship between compressive strength and curing time (containing fly ash). Note: $0 \% \mathrm{~s}$ denotes the value of the test when the fly ash content is $0 \%$ under standard curing conditions. $0 \% \mathrm{~s}$ denotes the value of the test when the fly ash content is $0 \%$ under temperature matched curing conditions.

1.813 MPa, and $1.648 \mathrm{MPa}$, respectively, under standard curing conditions and $1.959 \mathrm{MPa}, 1.991 \mathrm{MPa}, 1.943 \mathrm{MPa}$, and $1.777 \mathrm{MPa}$ respectively, under temperature matched conditions and the latter values are $83.0 \%, 88.5 \%, 107.2 \%$, and $107.8 \%$, respectively, of the compressive strength values under standard curing conditions. The ratio increases with the increase in the fly ash content. The results show that the temperature matched condition has a promoting effect on the strength development in the later stage with the addition of the fly ash, and this effect is not observed for the standard curing condition. The higher the fly ash content, the more obvious the effect.

Studies have shown that there are more hydration products during the early stage and fewer hydration products during the later stage in the temperature matched conditions compared with the standard curing conditions for pure cement $[26,27]$. This results in early strength increases and later strength decreases. The main reason is that high temperatures promote the hydration of the cement particles during the early stage, whereas the hydration products cover the surface of the cement particles and inhibit the hydration reaction during the later stage. For the foamed concrete with the fly ash under temperature matched conditions, the hydration reaction of the cement and the pozzolanic reaction of the fly ash are enhanced; the surface of the fly ash particles experience etching, the content of the gelling material increases, and the structure becomes denser (Figure 13).

In summary, when the casting density ranged from $400 \mathrm{~kg} / \mathrm{m}^{3}$ to $1000 \mathrm{~kg} / \mathrm{m}^{3}$ and no fly ash was used, the difference between the internal and external temperature of the cast-in-situ foamed concrete was significantly higher than $25^{\circ} \mathrm{C}$, which does not meet the requirements of the standard for the construction of mass concrete. When the casting density was $700 \mathrm{~kg} / \mathrm{m}^{3}$ and the fly ash content was $30 \%$, the temperatures met the 


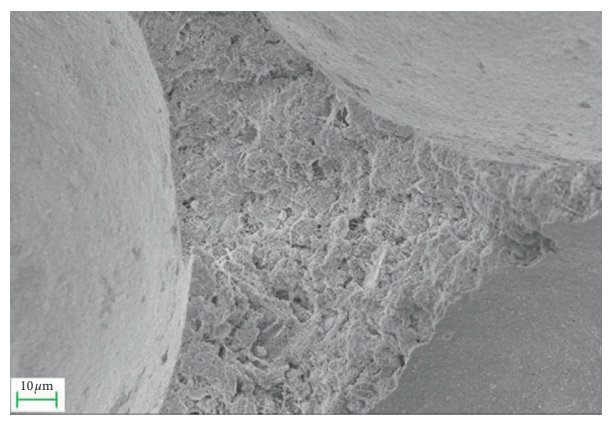

(a)

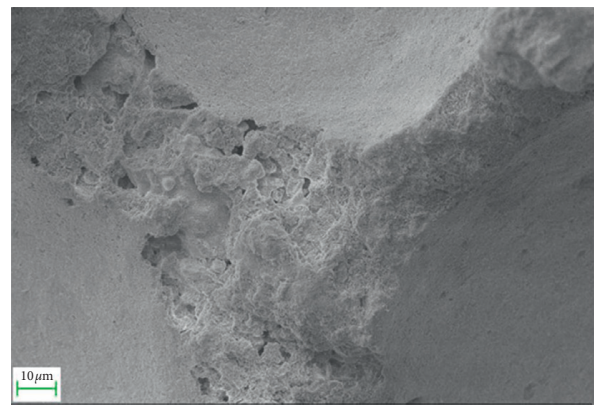

(c)

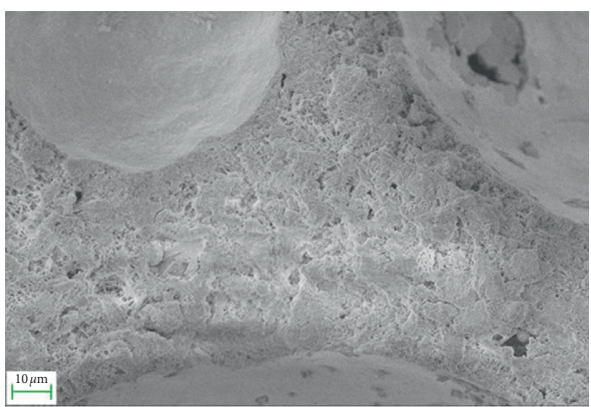

(b)

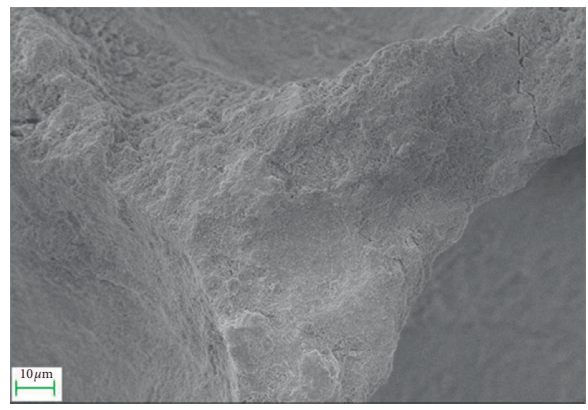

(d)

FIGURE 13: The SEM photographs of foamed concrete structures (28d): (a) standard curing conditions (pure cement), (b) temperaturematched curing conditions (pure cement), (c) standard curing conditions (containing fly ash), and (d) temperature-matched curing conditions (containing fly ash).

requirements of the standard for the construction of mass concrete. Therefore, it is necessary to consider field conditions and add a fly ash admixture or develop a system to contain moisture to meet the requirements.

\section{Field Test}

4.1. Introduction to Field Tests. The field tests consisted of four projects, and the details of the projects are shown in Table 2. Figure 14 shows an overview of the test sites. For project 3 , the water was tap water, and for the other projects, the water was drawn from the rivers using pumps. The casting temperature was adjusted using water. The layouts of the components in the four projects are shown in Figure 15. For project 1 , the height was $0.8 \mathrm{~m}$ and this distance was divided into two layers of $0.4 \mathrm{~m}$. Because the base was rough, the foamed concrete was cast with a thickness of $0.1 \mathrm{~m}$. For the other projects, the height exceeded $1.5 \mathrm{~m}$. The three bottom layers were tested and each layer was $0.5 \mathrm{~m}$. The bases were identical for projects 2,3 , and 4 , and the gravel layer was used for drainage, and a geomembrane was used to separate the water.

4.2. Results of Field Tests. Figure 16 shows the relationships between the temperatures at the eight positions and the casting times for the four projects. For project 1, at a casting temperature of about $13^{\circ} \mathrm{C}$, the maximum temperature increments are $48.95^{\circ} \mathrm{C}$ and $54.77^{\circ} \mathrm{C}$ for positions 2 and 5 , respectively, and the corresponding casting times are $17.5 \mathrm{~h}$ and $17 \mathrm{~h}$. For project 2, at a casting temperature of about $22.5^{\circ} \mathrm{C}$, the maximum temperature increments are $41.46^{\circ} \mathrm{C}$, $45.00^{\circ} \mathrm{C}$, and $47.76^{\circ} \mathrm{C}$ for the positions 2,5 , and 7 , respectively, and the corresponding casting times are $17.5 \mathrm{~h}, 17 \mathrm{~h}$, and $16 \mathrm{~h}$. For project 3 , at a casting temperature of about $21^{\circ} \mathrm{C}$, the maximum temperature increments are $43.25^{\circ} \mathrm{C}$, $47.14^{\circ} \mathrm{C}$, and $50.02^{\circ} \mathrm{C}$ for the positions 2,5 , and 7 , respectively, and the corresponding casting times are $17.1 \mathrm{~h}, 16.2 \mathrm{~h}$, and $14 \mathrm{~h}$. For project 4 , at a casting temperature of about $30^{\circ} \mathrm{C}$, the maximum temperature increments are $28.23^{\circ} \mathrm{C}$ and $29.79^{\circ} \mathrm{C}$ for positions 2 and 5, respectively, and the corresponding casting times are $17 \mathrm{~h}$ and $16.5 \mathrm{~h}$. For position 7 , the maximum temperature increment is $31.51^{\circ} \mathrm{C}$, and the corresponding casting time is $20.8 \mathrm{~h}$ at a casting temperature of about $27^{\circ} \mathrm{C}$. It is observed that when the upper layer is cast, the maximum temperature increment increases and the corresponding casting time decrease due to the heat transfer from the lower layer. For the four projects, the temperatures in position 1 at the bottom of the foamed concrete structures first increase with the casting times, reach the maximums, and then decrease slowly and stabilize. This occurs because of the contact with the lower layers. Due to the $0.1 \mathrm{~m}$ thickness of the foamed concrete layer, the stable temperature is high for project 1. A comparison of the temperatures at positions 3, 4, and 5 indicates that the temperatures of the second layers of the foamed concrete are affected by the first layers. They absorb heat during the early stage and release heat during the later stage.

Compared with projects 2, 3, and the indoor model tests, the results of project 4 show that reasonable cooling 
TABLE 2: Details of the projects.

\begin{tabular}{|c|c|c|c|c|c|}
\hline Project & $\begin{array}{l}\text { Design casting density } \\
\left(\mathrm{kg} / \mathrm{m}^{3}\right)\end{array}$ & $\begin{array}{l}\text { Measured casting density } \\
\left(\mathrm{kg} / \mathrm{m}^{3}\right)\end{array}$ & Mix proportions $\left(/ \mathrm{m}^{3}\right)$ & Construction location & Weather \\
\hline 1 & 1000 & $1018.5,1011.1$ & $\begin{array}{c}\mathrm{C}: \mathrm{F}: \mathrm{W}: \mathrm{A}=640: 0: 346: \\
448\end{array}$ & $\begin{array}{c}\text { Zigong city, Sichuan } \\
\text { province }\end{array}$ & $\begin{array}{c}\text { Wind speed: } 1-3 \\
\text { Humidity: } \\
78-80 \%\end{array}$ \\
\hline 2 & 650 & $651.4,656.7,654.2$ & $\begin{array}{c}\mathrm{C}: \mathrm{F}: \mathrm{W}: \mathrm{A}=405: 0: 223: \\
647\end{array}$ & $\begin{array}{l}\text { Chengdu city, Sichuan } \\
\text { province }\end{array}$ & $\begin{array}{c}\text { Wind speed: } 1-3 \\
\text { Humidity: } \\
83-86 \%\end{array}$ \\
\hline 3 & 670 & $657.8,663.5,675.6$ & $\begin{array}{c}C: F: W: A=420: 0: 231: \\
634\end{array}$ & $\begin{array}{c}\text { Huai'an city, Jiangsu } \\
\text { province }\end{array}$ & $\begin{array}{c}\text { Wind speed: } 1-3 \\
\text { Humidity: } \\
69-71 \%\end{array}$ \\
\hline 4 & 700 & $702.1,721.5,694.8$ & $\begin{array}{c}C: F: W: A=308: 132: \\
246: 602\end{array}$ & $\begin{array}{l}\text { Guiyang city, Guizhou } \\
\text { province }\end{array}$ & $\begin{array}{c}\text { Wind speed: } 0-4 \\
\text { Humidity: } \\
61-81 \%\end{array}$ \\
\hline
\end{tabular}

Note: $\mathrm{C}: \mathrm{F}: \mathrm{W}: \mathrm{A}=$ cement $(\mathrm{kg})$ : fly ash $(\mathrm{kg})$ : water $(\mathrm{kg})$ : air bubbles $(\mathrm{l})$.

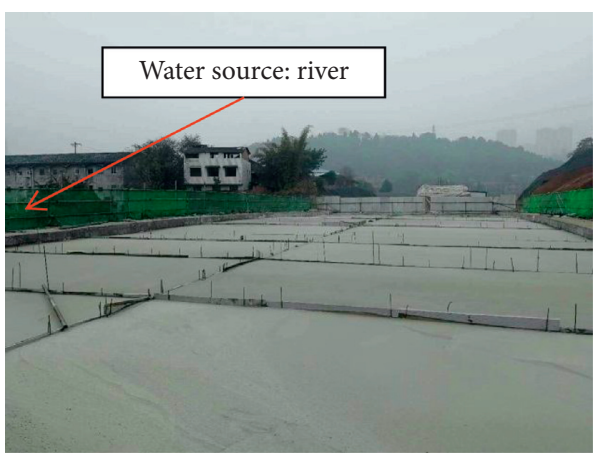

(a)

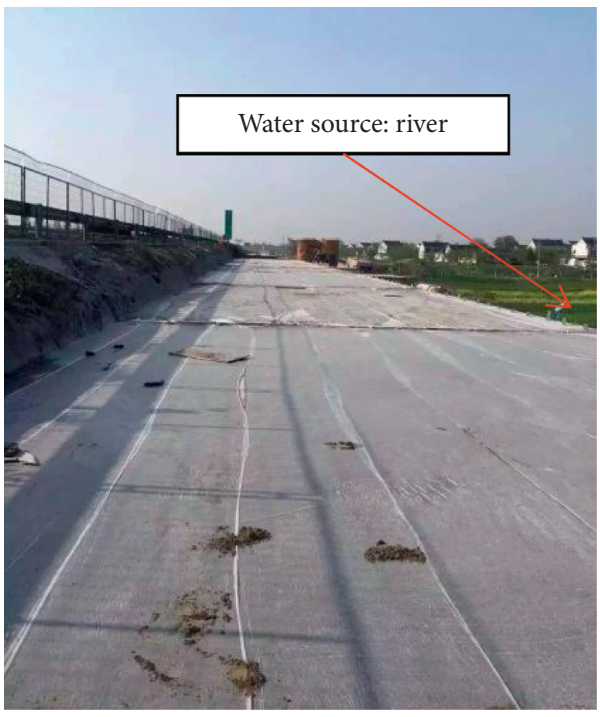

(c)

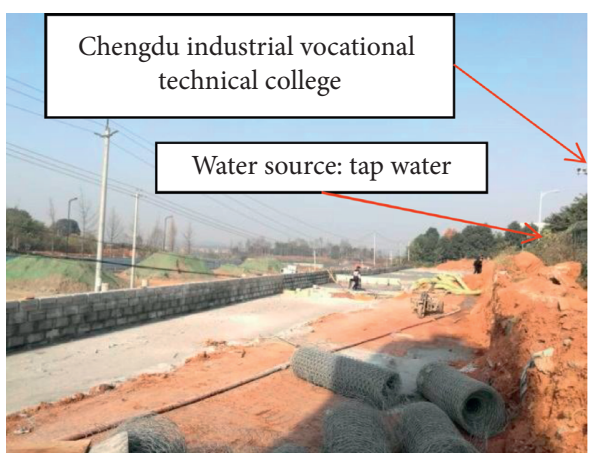

(b)

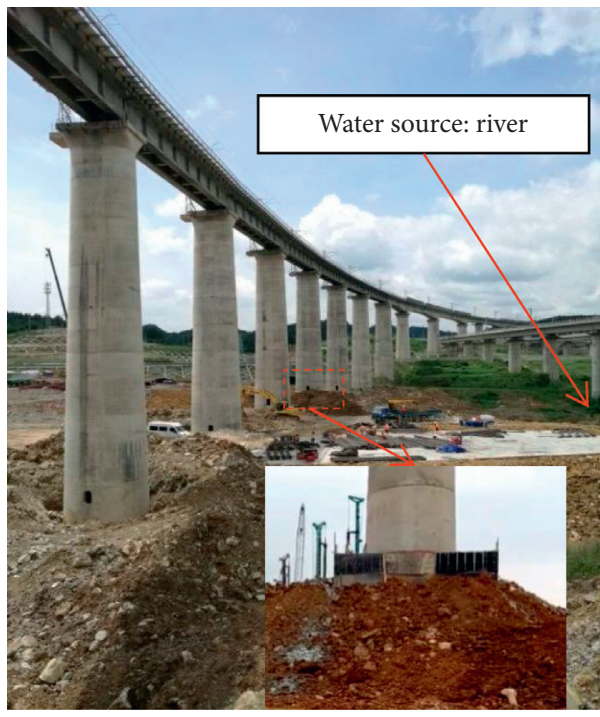

(d)

FIGURE 14: Overview of the test sites: (a) project 1 (fill on the top of the arch bridge), (b) project 2 (backfill behind the wall), (c) project 3 (widening of expressway), and (d) project 4 (backfill of high-speed station).

measures and the addition of fly ash decrease the maximum temperature increments and increase the corresponding casting times. When it rains, the foamed concrete structure is affected because the permeability coefficient of the foamed concrete is large and water can penetrate into the foamed concrete [25]. However, the upper layer is more affected than the internal portion. A large temperature difference between the internal and external portions of the structure 


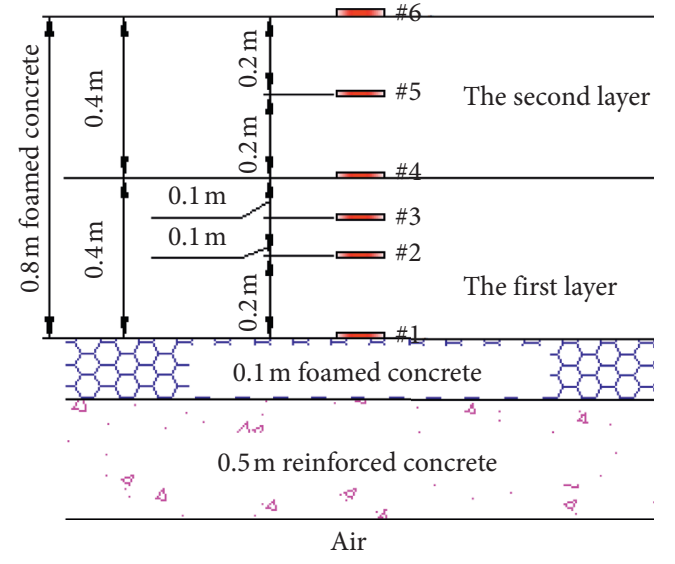

The thermometer

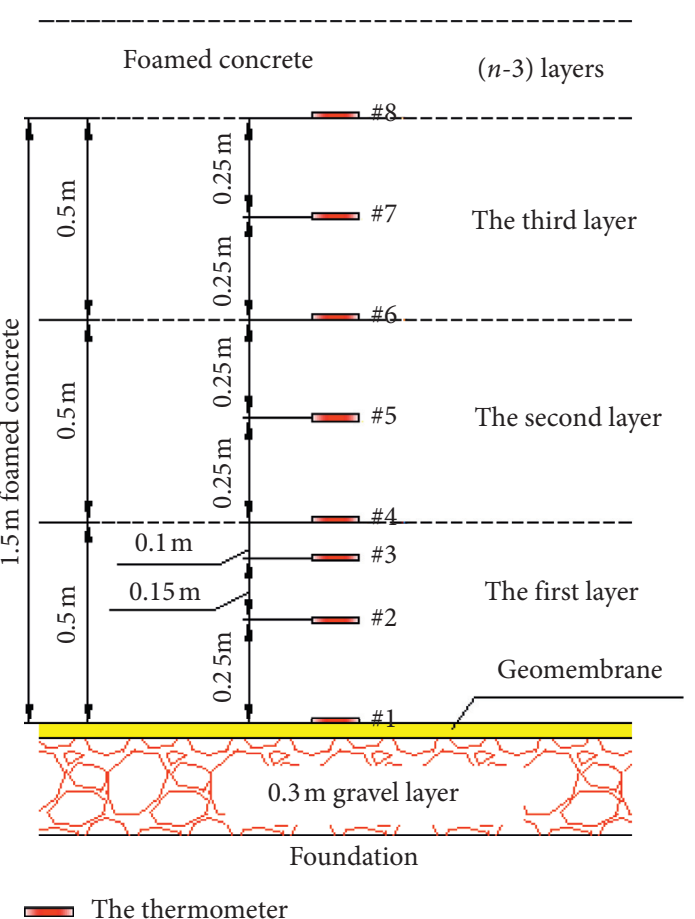

(b)

FIgURE 15: Layout of the components in (a) project 1 and (b) projects 2, 3, and 4.
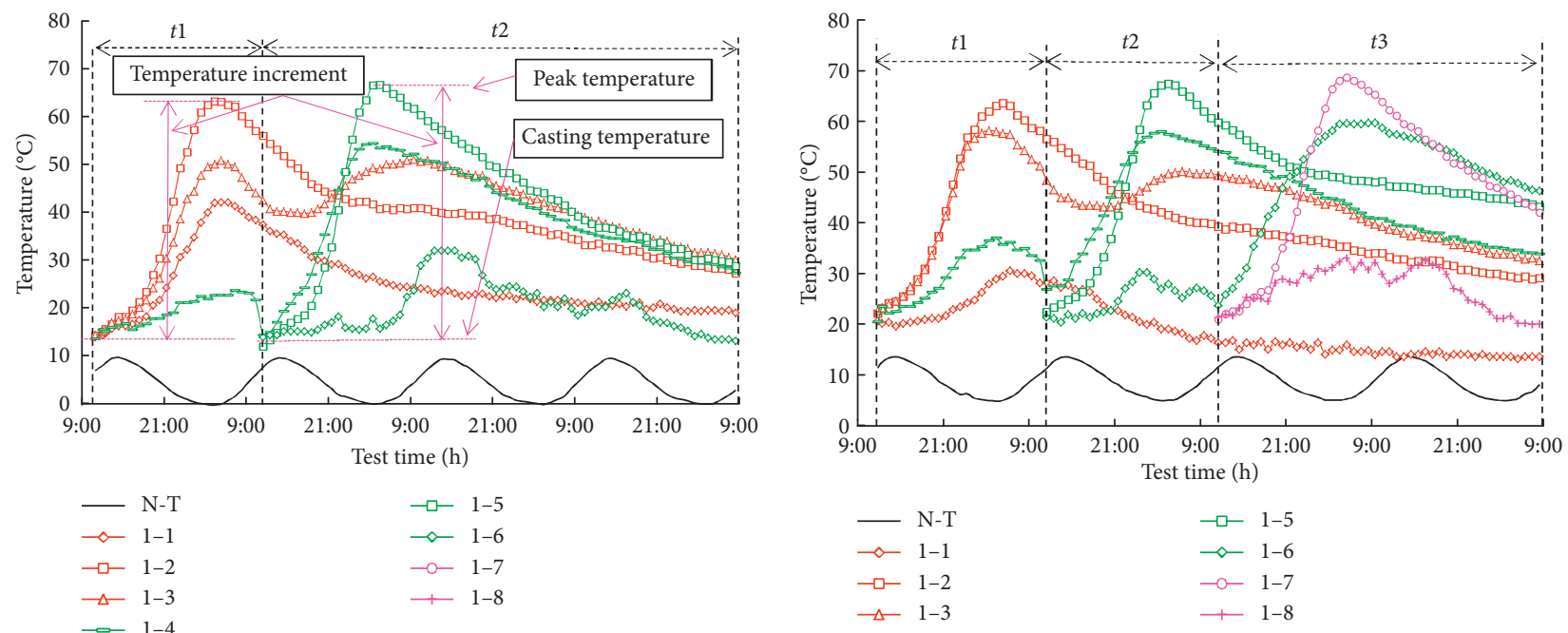

(a)

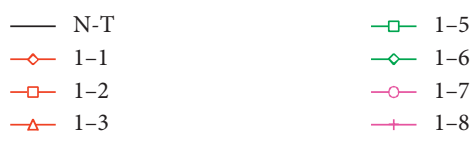

(b)

Figure 16: Continued. 


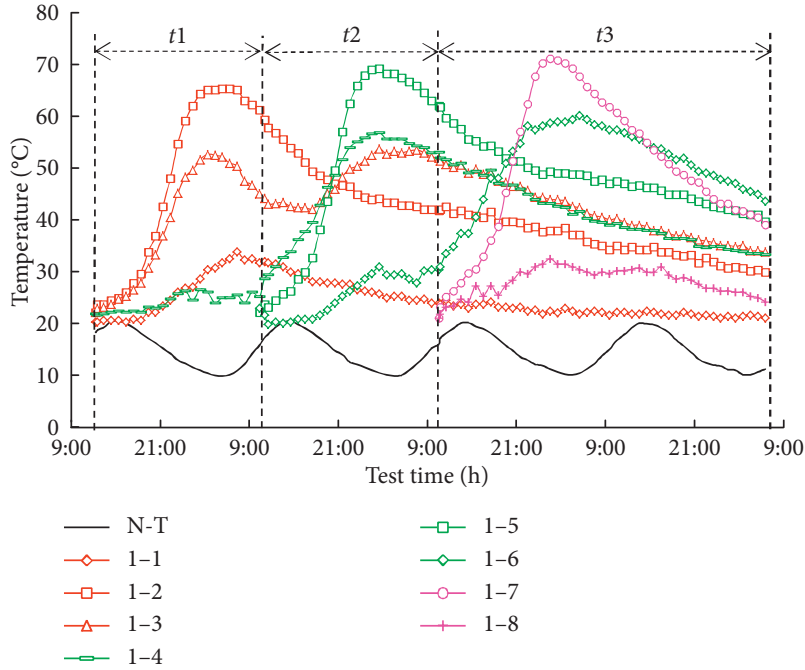

(c)

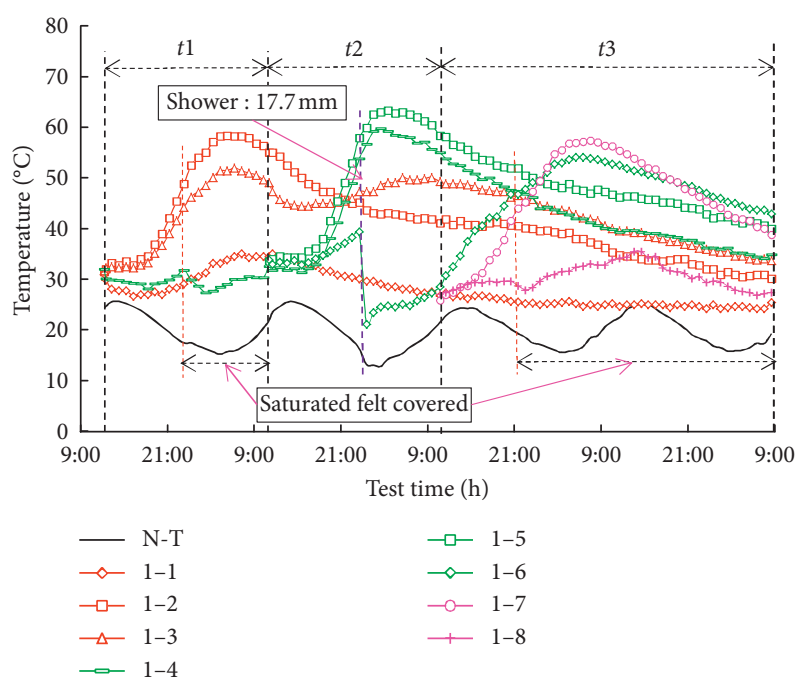

(d)

FIGURE 16: Relationship between temperatures and casting time: (a) project 1, (b) project 2, (c) project 3, and (d) project 4.

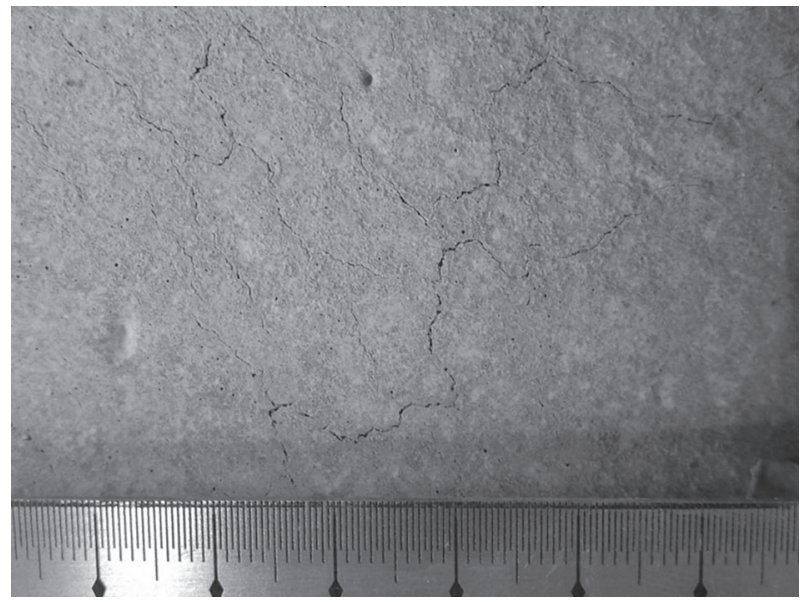

FIGURE 17: Crack fractures caused by the shower in project 4.

may cause numerous crack fractures (Figure 17) and reduces the quality of the project; therefore, rain or sudden cooling should be avoided.

The maximum temperature increments are higher for the indoor model test than the field test for the same casting density (Figure 18), but the corresponding casting times are similar. This is caused by the contact of the upper layer with the air and the heat transfer of the lower layer. The temperature decreases more slowly in the middle layer. Taking into account the results of the compressive strength tests under different curing conditions, this indicates that the strength should be reduced or the mix proportions should be improved. The maximum temperature increment is affected by the casting density, the fly ash content, and external influencing factors (wind speed, casting temperature, etc.). An experimental equation may be put forward in future studies when a larger dataset will be used.

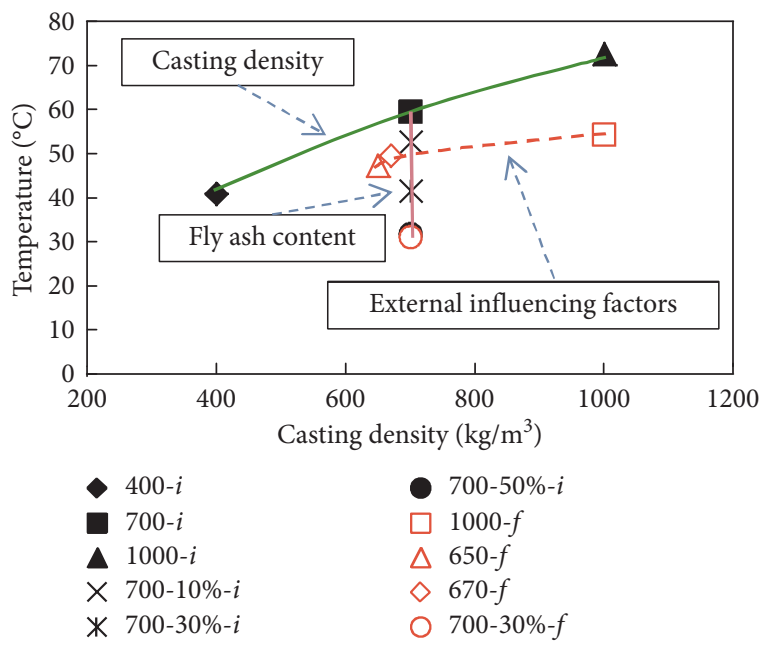

FIGURE 18: Maximum temperature increments of the foamed concrete. Note: $700-10 \%$-i denotes the value with a casting density of $700 \mathrm{~kg} / \mathrm{m}^{3}$ with $10 \%$ content of fly ash and the indoor model test. $700-10 \%$-f denotes the value with the casting density of $700 \mathrm{~kg} / \mathrm{m}^{3}$ with $10 \%$ content of fly ash and the field test.

\section{Conclusion}

The following conclusions can be drawn based on the experimental and comparative results.

(1) For the foamed concrete with the casting densities of $400 \mathrm{~kg} / \mathrm{m}^{3}, 700 \mathrm{~kg} / \mathrm{m}^{3}$, and $1000 \mathrm{~kg} / \mathrm{m}^{3}$, the peak temperatures are $62.33^{\circ} \mathrm{C}, 81.03^{\circ} \mathrm{C}$, and $94.27^{\circ} \mathrm{C}$, respectively, and the maximum values of the temperature change rate are $7.5^{\circ} \mathrm{C} / \mathrm{h}, 11.7^{\circ} \mathrm{C} / \mathrm{h}$, and $14.3^{\circ} \mathrm{C} / \mathrm{h}$ in position 1 . The peak temperature, the maximum temperature change rate, and the maximum temperature difference increase with an 
increase in the casting density at different positions in the foamed concrete.

(2) For the foamed concrete without an admixture, the strength increases significantly during the early stage and decreases during the later stage under temperature matched curing conditions. The strengths are improved for all curing times when the fly ash is added, and the effect increases with the increase in the fly ash content.

(3) Standard curing conditions and temperature matched conditions have an effect on the structure of composite cementitious materials mixed with fly ash at the later stage. The structure of foamed concrete hole wall is more compact under temperature matched conditions, increasing its compressive strength.

(4) Due to external factors occurring in the field tests, the maximum temperature increments are lower in the field tests than in the indoor model test for the same casting density. Reasonable cooling measures and the addition of the fly ash decrease the maximum temperature increments.

\section{Data Availability}

The data in this article allow researchers to verify the results, replicate the analysis, and conduct secondary analyses.

\section{Conflicts of Interest}

The authors declare that they have no conflicts of interest.

\section{Acknowledgments}

This work was supported by the Lanzhou Jiaotong University youth science foundation project (2019026), the Sichuan Science and Technology Support Project (2016JY0005), and the China Railway Science and Technology Research Plan Project (2015G002-K).

\section{References}

[1] X. Tan, W. Chen, Y. Hao, and X. Wang, "Experimental study of ultralight $\left(<300 \mathrm{~kg} / \mathrm{m}^{3}\right)$ foamed concrete," Advances in Materials Science and Engineering, vol. 2014, Article ID 514759, 7 pages, 2014.

[2] C. Hu, H. Li, Z. Liu, and Q. Wang, "Research on properties of foamed concrete reinforced with small sized glazed hollow beads," Advances in Materials Science and Engineering, vol. 2016, Article ID 5820870, 8 pages, 2016.

[3] Z. Liu, K. Zhao, C. Hu, and Y.-F. Tang, "Effect of water-cement ratio on pore structure and strength of foam concrete," Advances in Materials Science and Engineering, vol. 2016, Article ID 9520294, 9 pages, 2016.

[4] P. Onprom, K. Chaimoon, and R. Cheerarot, "Influence of bottom ash replacements as fine aggregate on the property of cellular concrete with various foam contents," Advances in Materials Science and Engineering, vol. 2016, Article ID 381704, 11 pages, 2016.
[5] Y. S. Jeong and H. K. Jung, "Thermal performance analysis of reinforced concrete floor structure with radiant floor heating system in apartment housing," Advances in Materials Science and Engineering, vol. 2016, Article ID 367632, 7 pages, 2015.

[6] A. A. Hilal, N. H. Thom, and A. R. Dawson, "On void structure and strength of foamed concrete made without/with additives," Construction and Building Materials, vol. 85, pp. 157-164, 2015.

[7] J. Jiang, Z. Lu, Y. Niu, J. Li, and Y. Zhang, "Study on the preparation and properties of high-porosity foamed concretes based on ordinary Portland cement," Materials \& Design, vol. 92, pp. 949-959, 2016.

[8] K. Ramamurthy, E. K. Kunhanandan Nambiar, and G. Indu Siva Ranjani, "A classification of studies on properties of foam concrete," Cement and Concrete Composites, vol. 31, no. 6, pp. 388-396, 2009.

[9] E. K. K. Nambiar and K. Ramamurthy, "Influence of filler type on the properties of foam concrete," Cement and Concrete Composites, vol. 28, no. 5, pp. 475-480, 2006.

[10] M. R. Jones and A. McCarthy, "Heat of hydration in foamed concrete: effect of mix constituents and plastic density," Cement and Concrete Research, vol. 36, no. 6, pp. 1032-1041, 2006.

[11] P. Bost, M. Regnier, and M. Horgnies, "Comparison of the accelerating effect of various additions on the early hydration of Portland cement," Construction and Building Materials, vol. 113, pp. 290-296, 2016.

[12] J. I. Escalante-Garcia and J. H. Sharp, "The microstructure and mechanical properties of blended cements hydrated at various temperatures," Cement and Concrete Research, vol. 31, no. 5, pp. 695-702, 2001.

[13] B. Xue, J. Pei, Y. Sheng, and R. Li, "Effect of curing compounds on the properties and microstructure of cement concretes," Construction and Building Materials, vol. 101, pp. 410-416, 2015.

[14] F. Sajedi and H. A. Razak, "Effects of curing regimes and cement fineness on the compressive strength of ordinary Portland cement mortars," Construction and Building Materials, vol. 25, no. 4, pp. 2036-2045, 2011.

[15] A. S. Tarasov, E. P. Kearsley, A. S. Kolomatskiy, and H. F. Mostert, "Heat evolution due to cement hydration in foamed concrete," Magazine of Concrete Research, vol. 62, no. 12, pp. 895-906, 2010.

[16] E. P. Kearsley and P. J. Wainwright, "The effect of high fly ash content on the compressive strength of foamed concrete," Cement and Concrete Research, vol. 31, no. 1, pp. 105-112, 2001.

[17] E. P. Kearsley and P. J. Wainwright, "Ash content for optimum strength of foamed concrete," Cement and Concrete Research, vol. 32, no. 2, pp. 241-246, 2002.

[18] N. Narayanan and K. Ramamurthy, "Structure and properties of aerated concrete: a review," Cement and Concrete Composites, vol. 22, no. 5, pp. 321-329, 2000.

[19] E. K. K. Nambiar and K. Ramamurthy, "Sorption characteristics of foam concrete," Cement and Concrete Research, vol. 37, no. 9, pp. 1341-1347, 2007.

[20] J. Dragaš, I. Ignjatović, N. Tošić, and S. Marinković, "Mechanical and time-dependent properties of high-volume fly ash concrete for structural use," Magazine of Concrete Research, vol. 68, no. 12, pp. 632-645, 2016.

[21] M. R. Jones and A. McCarthy, "Preliminary views on the potential of foamed concrete as a structural material," Magazine of Concrete Research, vol. 57, no. 1, pp. 21-31, 2005. 
[22] D. K. Panesar, "Cellular concrete properties and the effect of synthetic and protein foaming agents," Construction and Building Materials, vol. 44, pp. 575-584, 2013.

[23] W.-B. Liu and X. Zhang, "Study on volume stability of chemical foaming cement paste," KSCE Journal of Civil Engineering, vol. 21, no. 7, pp. 2790-2797, 2017.

[24] W. H. Zhao, J. J. Huang, Q. Su, and T. Liu, "Models for strength prediction of high-porosity cast-in-situ foamed concrete," Advances in Materials Science and Engineering, vol. 2018, Article ID 3897348, 10 pages, 2018.

[25] W. H. Zhao, Q. Su, W. B. Wang, L. L. Niu, and T. Liu, "Experimental study on the effect of water on the properties of cast in situ foamed concrete," Advances in Materials Science and Engineering, vol. 2018, Article ID 7130465, 11 pages, 2018.

[26] M. Ahmaruzzaman, "A review on the utilization of fly ash," Progress in Energy and Combustion Science, vol. 36, no. 3, pp. 327-363, 2010.

[27] Q. Zeng, K. Li, T. Fen-chong, and P. Dangla, "Determination of cement hydration and pozzolanic reaction extents for flyash cement pastes," Construction and Building Materials, vol. 27, no. 1, pp. 560-569, 2012. 